\title{
Profit Analysis of Papaya Crops under Greenhouses as an Alternative to Traditional Intensive Horticulture in Southeast Spain
}

\author{
Mireille N. Honoré ${ }^{1} \mathbb{D}$, Luis J. Belmonte-Ureña ${ }^{1,2, * \mathbb{C}}$, Asensio Navarro-Velasco ${ }^{3}$ and \\ Francisco Camacho-Ferre ${ }^{1}(\mathbb{D})$ \\ 1 CIAIMBITAL Research Center, Agrifood International Excellence Campus, University of Almería, \\ Carretera Sacramento s/n, 04120 Almería, Spain \\ 2 Department of Economics and Business, University of Almería, Carretera Sacramento s/n, \\ 04120 Almería, Spain \\ 3 Vitalplant Nursery-Paraje Balsaseca, San Isidro-Níjar, 04117 Almería, Spain \\ * Correspondence: lbelmont@ual.es; Tel.: +34-950-214-788
}

Received: 15 July 2019; Accepted: 9 August 2019; Published: 14 August 2019

\begin{abstract}
The high-yield agricultural model in Almería is based on eight different crops. Having led fruit and vegetable exports in Spain for more than 50 years, a decrease in melon and watermelon growing areas in Almería caused a change in supply that affected the model's profit. Papaya cultivation could reactivate the profit of the agricultural model in Almería and also improve the available product range. The papaya crop needs greenhouse infrastructures high enough to contain the growth and size of the plants during a cycle crop, which is possible in most of the greenhouses of the Horticultural production model of Almería. The papaya harvests obtained in the region meet the quality requirements demanded by European markets. Furthermore, yields obtained are equal or higher than yields obtained by other producing countries. This crop improves profit compared with the profit obtained from the rotation of other horticultural crops that have been traditionally grown in the region.
\end{abstract}

Keywords: Carica papaya; alternative crop; transplant of sex-identified plants; productive structure for intensive crops

\section{Introduction}

In the last 50 years, the province of Almería, in southeast Spain, has experienced a large economic transformation. The development of innovative and intensive agriculture has generated significant economic growth in the region with a positive impact on the welfare of families who live there [1]. This growth happened even though the region did not follow a proposal in European rural development guidelines to adopt an economic diversification strategy [2]. The productive diversification strategy is valid and advisable for developing countries, although it cannot be extrapolated to cover the whole of an increasingly liberalized world [3]. The agricultural sector in Almería has invested in new greenhouse architectures and technology to improve climate management and hydric resources. Moreover, product specialization has generated a local production system incorporating cooperation mechanisms that share innovative experiences and specialist knowledge.

The product specialization in Almería, sometimes called a high-yield agricultural model, is based on eight crops grown under plastic greenhouses: tomato, pepper, cucumber, courgette, aubergine, green bean, melon, and watermelon. Currently, such model is found in a productive maturity stage after developing a powerful commercialization channel. Increasing competition with third world countries is met through the reduction of production costs-mainly reducing labor and transportation 
costs $[4,5]$. Other costs, derived from crop insurance and greenhouse structures, are increasingly common among fixed costs, of a financial nature, on agricultural farms [6,7].

Production costs can be very variable among different production systems, due to the great differences in the technological levels and equipments used in each case. There are differences between different agrosystems due to the technological level of greenhouse cultivation, the contributions of energy, and inputs that they require [8]. However, one of the main components of the costs is the amortization of the investment in the structure of the greenhouse, in the equipment of fertigation, and in the climatic control. Therefore, as described Testa et al. [9], in the Mediterranean basin most of the greenhouses are built with low cost and technology in comparison to the greenhouses of Northern Europe [10,11], having plastic coverings and few climate control systems [12,13]. Thanks to the mild winters and the high solar hours, the structures do not need more investments to ensure a very aceptable quality crop. Genetic improvements of vegetables contribute to producing fruits that have a longer post-harvest life [14,15].

The adaptation process of the agricultural sector in Almería is demonstrated by the reorganization of the area grown, as shown in Table 1.

Table 1. Evolution of the wintering area by type of crop (2009-2018) in hectares.

\begin{tabular}{cccccccccc}
\hline Year & Tomato & $\begin{array}{c}\text { Sweet } \\
\text { Pepper }\end{array}$ & Cucumber & Aubergine & Courgette & $\begin{array}{c}\text { Green } \\
\text { Bean }\end{array}$ & Melon & Watermelon & $\begin{array}{c}\text { Total Area } \\
\text { Green-House }\end{array}$ \\
\hline 2009 & 10,147 & 7505 & 4430 & 1868 & 4717 & 921 & 4447 & 5216 \\
2010 & 9939 & 7475 & 4498 & 1824 & 5020 & 776 & 4039 & 5516 & 39,251 \\
2011 & 9050 & 7300 & 4550 & 1924 & 5265 & 680 & 3539 & 4916 \\
2012 & 9124 & 7388 & 4535 & 2190 & 5789 & 1170 & 3740 & 5665 & 37,224 \\
2013 & 10,358 & 8461 & 4920 & 2006 & 6448 & 1321 & 4200 & 6400 \\
2014 & 11,206 & 9378 & 4839 & 1908 & 7219 & 1387 & 2591 & 7100 \\
2015 & 10,345 & 9326 & 4979 & 2447 & 7477 & 1439 & 2946 & 8378 \\
2016 & 10,940 & 9491 & 5026 & 2300 & 7630 & 1340 & 2467 & 8590 \\
2017 & 10,220 & 10,310 & 4980 & 2150 & 7970 & 1030 & 2220 & 8940 \\
2018 & 10,380 & 10,181 & 5099 & 2209 & 7860 & 510 & 2290 & 9860 \\
\hline
\end{tabular}

Source: Own elaboration made with data provided by the Provincial Delegation of the Regional Department of Agriculture of the Andalusian Regional Government in Almería (Spain).

Considering the data obtained from the previous table and the cartographic base of greenhouses in Almería [16], three important conclusions are obtained:

1. The soil occupancy rate from 2009 to 2018 varied from 1.38 to 1.59 , which means that the area used for short cycles is greater than that used for long cycles. Soil occupancy is the rate between the addition of areas occupied by the different crops developed in a season by the soil area available for the greenhouse. When a farmer cultivates only a crop in the greenhouse along the season in a long cycle, this rate will be equal to 1 . When the farmer cultivates two short cycles in the same greenhouse (one in autumn-winter and a second in spring-summer) this rate will be equal to 2 . An increase in the soil occupancy rate shows an augmentation of the use of short cycles in the greenhouses. This is a dimensionless number.

2. In one decade, the area used for greenhouses has increased by 3123 hectares.

3. The area used for each crop has changed. There was a decrease of 2157 and 411 hectares for melon and green bean, respectively. Meanwhile, the area used for the other crops has grown, mainly watermelon (4644 ha), courgette (3143 ha), and pepper (2676 ha).

With respect to commercialization, farmers maintained revenues over many years, mainly due to the stability of the average prices of the vegetable commodities (see Figure 1 and Table 2) produced in Almería, all mentioned in Table 1. However, as production costs increased year after year, the margins fell for units of product sold. 


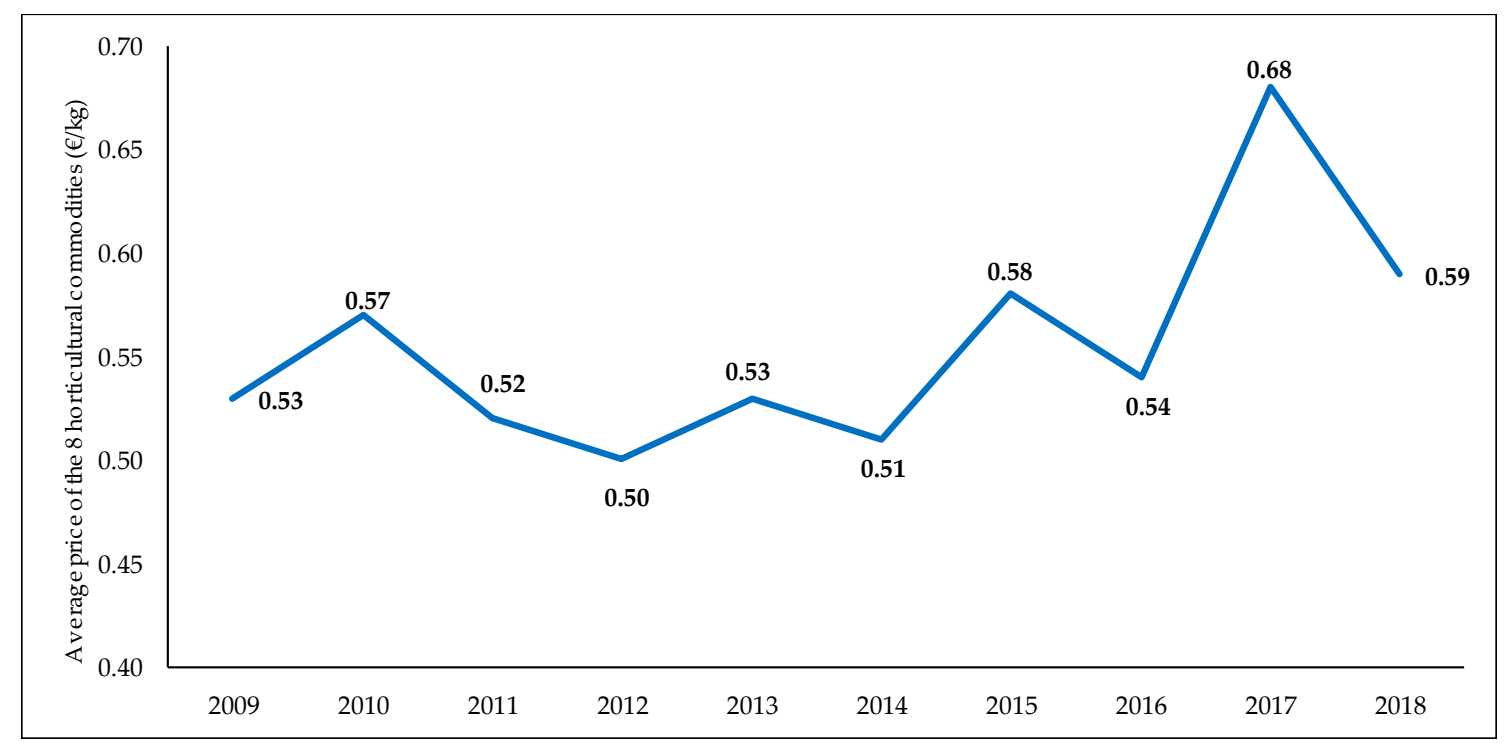

Figure 1. Evolution of the average price of the eight horticultural commodities grown under plastic greenhouses (tomato, pepper, cucumber, courgette, aubergine, green bean, melon, and watermelon) produced in the province of Almería (Spain) from 2009 to 2018, in $€ \cdot \mathrm{kg}^{-1}$ [17]. Source: Own elaboration made with data provided by the Provincial Delegation of the Regional Department of Agriculture of the Andalusian Regional Government in Almería (Spain) (2009 to 2018) [17].

The data of Figure 1 are obtained from Tables 1 and 2, calculating the weighted mean with the areas of each crop.

Table 2. Average price of the eight horticultural commodities grown under plastic greenhouses (watermelon, melon, courgette, cucumber, aubergine, tomato, pepper, and green bean) produced in the province of Almería (Spain) from 2009 to 2018, in $€ \cdot \mathrm{kg}^{-1}$ [17].

\begin{tabular}{ccccccccccc}
\hline Crop & $\mathbf{2 0 0 9}$ & $\mathbf{2 0 1 0}$ & $\mathbf{2 0 1 1}$ & $\mathbf{2 0 1 2}$ & $\mathbf{2 0 1 3}$ & $\mathbf{2 0 1 4}$ & $\mathbf{2 0 1 5}$ & $\mathbf{2 0 1 6}$ & $\mathbf{2 0 1 7}$ & $\mathbf{2 0 1 8}$ \\
\hline Watermelon & 0.242 & 0.249 & 0.332 & 0.250 & 0.263 & 0.278 & 0.372 & 0.318 & 0.327 & 0.407 \\
Melon & 0.336 & 0.398 & 0.376 & 0.395 & 0.381 & 0.367 & 0.451 & 0.470 & 0.448 & 0.535 \\
Courgette & 0.499 & 0.670 & 0.380 & 0.475 & 0.564 & 0.463 & 0.789 & 0.489 & 0.681 & 0.555 \\
Cucumber & 0.577 & 0.446 & 0.434 & 0.435 & 0.542 & 0.449 & 0.467 & 0.418 & 0.640 & 0.501 \\
Aubergine & 0.570 & 0.503 & 0.448 & 0.418 & 0.591 & 0.511 & 0.453 & 0.371 & 0.728 & 0.513 \\
Tomato & 0.560 & 0.646 & 0.511 & 0.571 & 0.525 & 0.538 & 0.559 & 0.527 & 0.714 & 0.621 \\
Pepper & 0.723 & 0.746 & 0.882 & 0.668 & 0.768 & 0.647 & 0.733 & 0.824 & 0.908 & 0.755 \\
Green Bean & 1.281 & 0.902 & 1.459 & 1.518 & 1.360 & 1.127 & 1.575 & 1.455 & 1.747 & 1.584 \\
Average & 0.599 & 0.570 & 0.603 & 0.591 & 0.624 & 0.548 & 0.675 & 0.609 & 0.774 & 0.684 \\
\hline
\end{tabular}

Source: Own elaboration made with data provided by the Provincial Delegation of the Regional Department of Agriculture of the Andalusian Regional Government in Almería (Spain) (2009 to 2018) [17].

Two analyses can be made considering this price stability situation. On one hand, supply must decrease to meet a stable demand and, on the other hand, the product range that this model offers must increase to prevent loss of competitiveness within the sector.

Within this context, in order to expand the range of agricultural commodities offered by the province of Almería, we thought about working with an exotic species for the European continent such as papaya, obtaining production data and quality of the same as well as economic results of the sales and expenses incurred for production. The reasons for selecting the papaya crop in our study are twofold. First of all, in Europe, papaya consumption is growing due to its nutritional properties and high medicinal value $[18,19]$. Furthermore, the proximity of consumer markets to Southeast Spain allows fruits to be harvested at a more advanced stage of maturity compared to exporting countries from outside Europe, a timeline which improves the quality of the papaya. 
Papaya (Carica papaya L) comes from southern Mexico and Nicaragua [20] and is a widely produced crop in the tropics. Until recently, the cultivation of this plant was carried out in tropical or subtropical regions. Nowadays, papaya is being cultivated in new regions using climatic protection techniques. In the province of Almería, some trials made on a very small scale by producers of the region have confirmed that this type of crop is well adapted to the agronomic conditions and production infrastructure found in southeast Spain. Additionally, there is an existing horticultural commercial network that provides a business infrastructure. The fruit were well accepted by the consumers. Additionally, in the economic situation of the province of Almería where there is a loss of competitiveness within the sector, we have observed that the papaya fruit is highly demanded by the European northern countries and that the average price is higher than the eight horticultural commodities cultivated under greenhouses.

In response to consumer demand we need to consider how product range can be expanded using the Protected Horticulture model from Almería. The trading sector has an agile commerce channel to sell the horticultural products, which has developed over more than 40 years, with an annual turnover of 3.5 million tonnes of fruit and vegetables for national and international markets. Within this framework and taking into account the special agro-environmental conditions and experience in the horticultural sector of Almería, the usual range of fruit and vegetables grown in this region could be extended, introducing a new crop such as papaya.

In the last decade, the demand for tropical fruits has grown at a constant and sustained rate. Papaya is the third most consumed tropical fruit, after mango and pineapple, and production reached $13,169,443 \mathrm{t}$ in 2017 [21]. Although the increase in the papaya supply mostly derives from Indian production, this fruit has become a good source of revenue for many Asian and Latin American countries too.

In the last five-year period, over $50 \%$ of papaya production was distributed to the United States of America. In Europe, papaya consumption is consolidating due to the nutritional and high medicinal properties of the fruit $[18,19]$. The biggest importers of papaya in Europe are the United Kingdom, Holland, and Germany [22].

The Canary Islands (Spain is Europe's largest papaya producer with cultivation on 350 ha [23]. This cultivation area is expanding, meanwhile the area used for growing tomatoes is decreasing. Papaya is also grown in Continental Europe. In 2012, cultivation first began in the province of Almería on $6000 \mathrm{~m}^{2}$. The production obtained was marketed locally as "papaya of Almería". Early on, studies took place to understand both the adaptation of this crop to the southeast Spain, greenhouse production system, and how different cultivation practices could improve yield.

The aim of this article is to present the advantages of incorporating a subtropical crop like papaya and increase the range of products offered by the Almería agricultural sector, which tends to concentrate the supply on only eight horticultural commodities. Papaya cultivation was selected for several reasons. First, there is an important European demand for this crop, and India is currently the first supplier. Another reason for this choice is that Papaya can be cultivated under greenhouses with the productive conditions of the Spanish southeast. For both reasons, a field study was carried out in Almería to assess the quality of a Papaya cultivation grown under a naturally ventilated greenhouse and to estimate the net profit before taxes that the papaya crop would generate, over a period of 2.5 years (30 months). A comparison is made with the most common horticultural crop combinations in South Eastern Spain, crops that have been grown in the province of Almería for four decades. Finally, from the point of view of the distribution, this crop has been incorporated into the offer of several suppliers in the region, even with scarce importance due to the reduced cultivated area now in the province.

\section{Materials and Methods}

An experiment was conducted to obtain the product. From this experiment, production and quality (agronomic) data were obtained alongside economic data concerning when papaya was put on 
the market. The greenhouse where it was planted has an area of $1800 \mathrm{~m}^{2}$, and this area corresponds with the area of the greenhouse located in the experimental plot of the University of Almería.

\subsection{Location of the Experiment}

The experiment was conducted at the research station "Catedrático Eduardo Fernández", which belongs to the Foundation of the University of Almería-Anecoop. It is located in a place called "Los Goterones" in Almería, 36 51' North latitude and $2^{\circ} 17^{\prime}$ West Longitude, at $90 \mathrm{~m}$ above sea level.

\subsection{Greenhouse Infrastructure}

The plants were transplanted in a "multi-tunnel" greenhouse with an area of $1800 \mathrm{~m}^{2}$, a gutter height of $4.50 \mathrm{~m}$, and a ridge height of $5.70 \mathrm{~m}$. The covering was made from three layers of plastic film (low-density polyethylene, 200 microns thick). Due to the climatology of the region and the needs of the papaya plant to be within the above parameters, from June to September three side walls were opened and the East oriented side wall was closed; wind is warm in this orientation, so there is an excessive decrease in the relative humidity in the interior of the greenhouse. To avoid this decrease in relative humidity, white plastic mulch film was placed on the soil, in alternate lines, forming small reservoirs which were filled with water to produce evaporation (Figure 2). In winter, this mulch film was not filled with water and alternate lines were mulched with black plastic film because covering the whole soil surface decreases relative humidity.

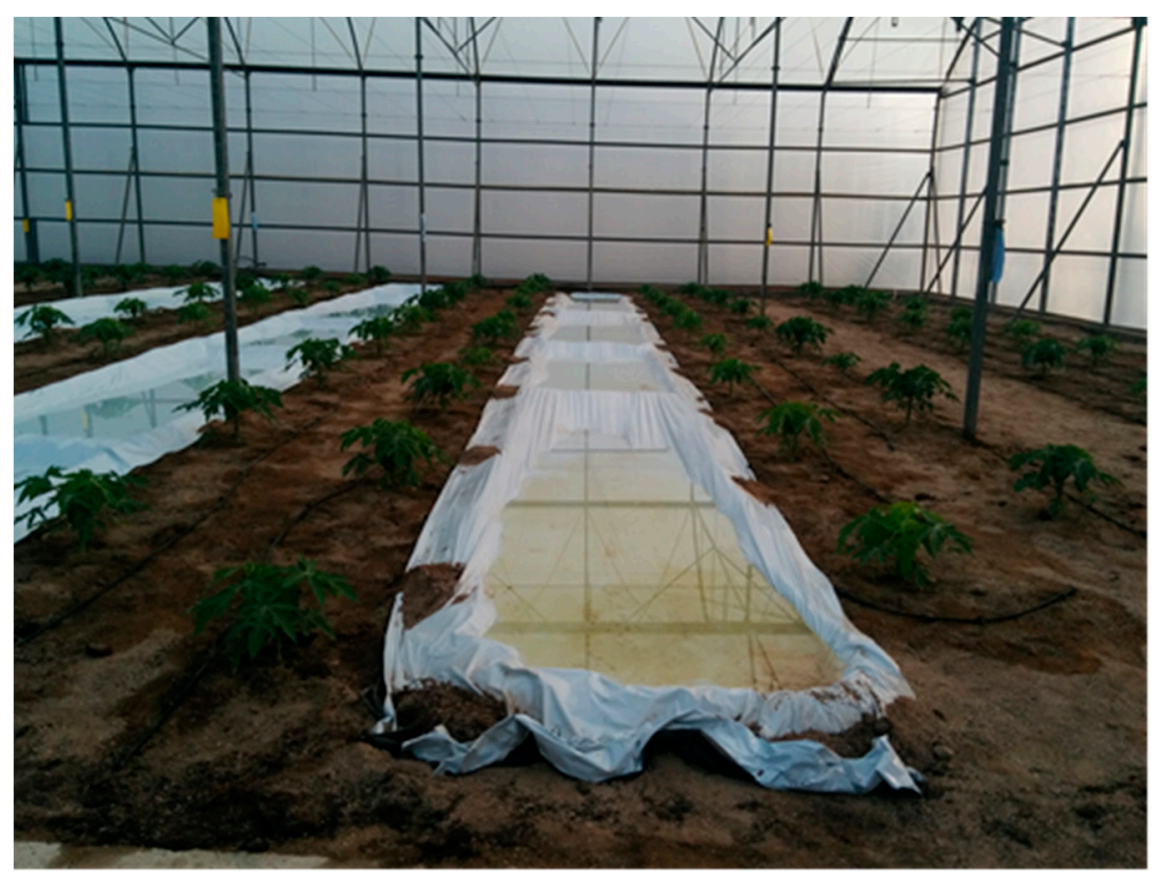

Figure 2. Plastic mulching of part of the floor surface for the incorporation of humidity in the environment.

The soil used was enhanced to place its quantitative parameters of nutrients and organic matter within the range of fertile soils. The soil was protected with a sand covering, which is typical in this region, as described by Camacho and Fernández [24]. During the past 13 years, tomato, pepper, courgette, and cucumber were grown in this soil.

Irrigation was carried out through a localized irrigation system of high frequency (drip irrigation) using discharge drippers $3 \mathrm{~L} \cdot \mathrm{h}^{-1}$ with a density of 1.6 drippers $/ \mathrm{m}^{2}$. 


\subsection{Plant Material}

The vegetal material used was Intenzza papaya seeds, belonging to the "Semillas del Caribe" company (Jalisco, Mexico) [25]. Out of the current varieties grown under greenhouse in Continental Europe, this specific variety was chosen because it is the leading variety. The vegetal material was prepared in the nursery to conduct the experiment in the plot described above.

The characteristics of the planted papaya were a sex-identified Intenzza Papaya with a rootball (pot) of $2 \mathrm{~L}$ and an approximate plant height of $60 \mathrm{~cm}$. The sowing date was 10 October 2015 and the early sex-identification was made on 20 November 2015, 40 days after sowing (das).

The transplant to the final field was made on 23 March 2016. A total of 30 months (February 2016 to July 2018) is the period during which the analysis of the data of this experiment was made. The papaya cultivation in this trial started on March 2016 (transplanting date). Preparation of the soil was in February 2016 and during July of 2018, when the plants were taken off.

The distribution of plants was made in paired and staggered rows with a distance of $2.20 \mathrm{~m}$ (corridors) between paired rows, $1.00 \mathrm{~m}$ between lines and $2.00 \mathrm{~m}$ between plants. Under these distributions, there was a density of 2700 plants/ha. The total area of the experiment was $1650 \mathrm{~m}^{2}$ used for growing, the rest of covered area was used as walkways.

\subsection{Fertilization and Crop Protection}

The soil had a clay loam texture with $0.45 \%$ of organic matter and $\mathrm{pH}$ and electrical conductivity (EC) values, in the saturation extract, of 7.80 and $4.65 \mathrm{dS} \cdot \mathrm{m}^{-1}$ respectively.

The water used had an EC of $1.4 \mathrm{dS} \cdot \mathrm{m}^{-1}$ and a $\mathrm{pH}$ of 7.13 . Nutrients were applied by drip irrigation.

One week after transplanting, the addition of fertilizer began. Additionally, the EC of irrigation water increased by $0.5 \mathrm{dS} \cdot \mathrm{m}^{-1}$ until it progressively reached $2 \mathrm{dS} \mathrm{m}^{-1}$, the maximum amount of EC reached by addition of nutrients, for plants developed from the beginning to the end of the harvest (Figure 3).

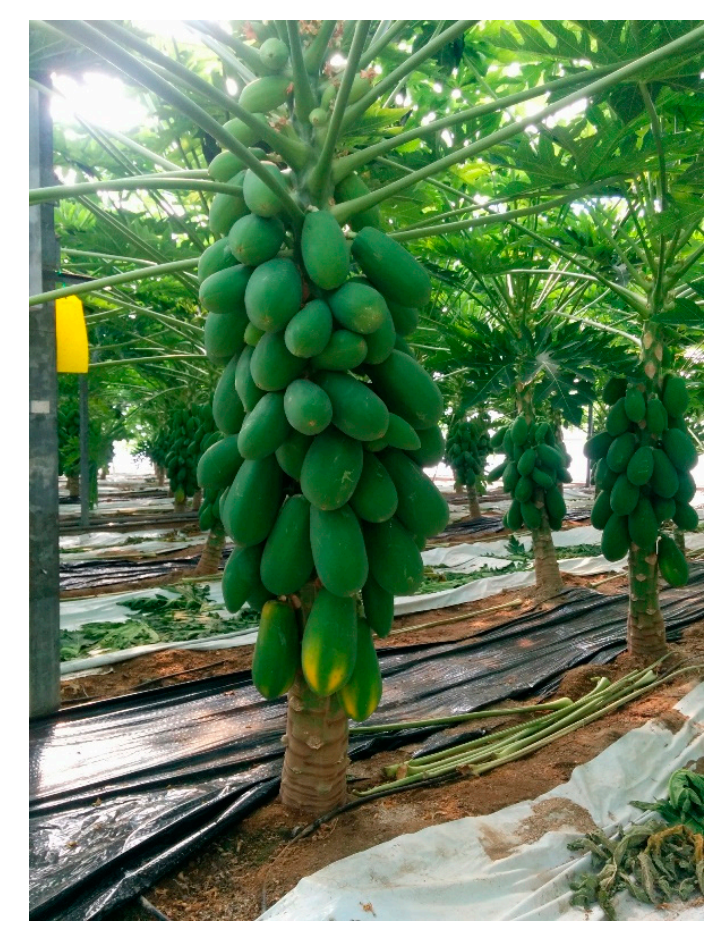

Figure 3. Papaya plant under greenhouse with fruits close to harvest.

Crop pests and diseases were controlled with biological control with releases of beneficial insects, or natural pesticides. Tetranichus urticae were controlled with Phytoseiulus persimilis and Amblyseius 
californicus releases, in addition to the occasional appearance of Stethorus punctillum. The small aphids Aphis gossypii were controlled with preventive Lysiphlebus testaceipes and Aphidius colemani releases on cereal banker plants, which were infected by us with a specific aphid, Rhopalosiphum padi. In winter, Botrytis cinerea appeared in small areas injuring the stem, which caused the fall or removal of the lower petioles. It was controlled by applying Samurai ${ }^{\circledR}{ }_{-}$-Nutricrop paste (Almería, Spain) (a product made from natural clays that isolates the internal tissues of the plant from the outside environment) locally and on the injured stem. At the end of winter, Oidium caricae also appeared on small areas and it was controlled by applying Ospo $\mathrm{V}^{\circledR}$-Agrotecnología sulphur (Orihuela, Spain) (a product made from vegetal extracts, flavonoids, alkaloids, phenols, macro and microelements, polysaccharides and microorganism extracts) and Larekigreens ${ }^{\circledR}$, Biofungitek, (Derio, Spain) (a product made from potassium carbonate and vegetal extracts).

\subsection{Harvest Time}

The fruit harvest was carried out from October 2016 to the beginning of August 2017, and it began 193 days after transplanting (dat), first season. Then it began at the end of August 2017 until the middle of June 2018 (second season). Within the mentioned periods, the harvest was carried out every week in color stage 2 to 3 using the color stage values of Santamaría-Basulto et al. [26]. The maturity stage 2 corresponds with yellow coloring fruit between $25 \%$ and $33 \%$. The maturity stage 3 corresponds with yellow coloring fruit between $33 \%$ and $40 \%$. In the spring-summer weeks, the harvest was only carried out at maturity stage 2 . The harvest was carried out one day per week in winter and four days per week in spring-summer.

The fruits were weighted with a BBA422-60LA BASIC (Mettler Toledo, L'Hospitalet de Llobregat, Spain) scale with a maximum capacity of $60 \mathrm{~kg}$ and $\pm 1 \mathrm{~g}$ sensitivity.

\subsection{Comparison of Economic Data between the Papaya Cultivation and Crops currently Grown in the High-Yield Agricultural Intensive Model in Almería}

The economic comparison was made under the principles of maximization of benefits by farmers. Hence, to evaluate the opportunity of the different crop alternatives, the net profit before taxes (NPbt) has been used for each possible crop combination [27-29]. NPbt was calculated as a difference between the total annual sales revenue (TAR) and the total costs (TC) incurred in each campaign.

$$
\mathrm{NPbt}=\mathrm{TAR}-\mathrm{TC}
$$

With NPbt: Net Profit before taxes; TAR: Total Annual Revenue; TC: Total costs.

The structure of revenues and expenditure which was followed to conduct this research, was agreed by the "Experimental Plot of the Foundation University of Almería-Anecoop", where the experiment was conducted. Additionally, the structure obtained by Toresano and Camacho for Agroseguros, S.A.-Spain [30] was followed, data not published corresponding with the Provision of Services PS201200000000000184 of the Research Results Transfer Office (OTRI) of the University of Almería.

To make a comparison between the crops, five different agronomic alternatives were taken as a reference from the species with which the model works (four cucurbits, three solanaceous, and one leguminous plants). In this sense, a different crop was planted after each cycle, except for the case of long-cycle tomato. Therefore, the first four alternatives were formed by crops developed in short cycles, every six months (two harvest per year), and the fifth alternative began with a courgette crop, short cycle (6 months), and when it finished, two tomato harvests followed it, long cycle (12 months), until total period of 30 months was completed.

These alternative crops are usual in the intensive agriculture model in the Spanish southeast [8].

To make an economic comparison, the horticultural alternatives studied against the new papaya crop were:

Horticultural 1: watermelon $(2016)+$ tomato $(2016)+$ courgette $(2017)+$ pepper $(2017)+$ watermelon (2018). 
Horticultural 2: tomato (2016) + cucumber (2016) + aubergine (2017) + green bean (2017) + melon (2018).

Horticultural 3: melon (2016) + pepper (2016) + watermelon (2017) + tomato (2017) + melon (2018).

Horticultural 4: courgette $(2016)+$ aubergine $(2016)+$ melon $(2017)+$ pepper $(2017)+$ watermelon (2018).

Horticultural 5: Courgette (2016) + tomato (2016-2017) + tomato (2017-2018).

The technical characteristics of the productive infrastructures, to obtain economic data with respect to investment cost and its corresponding depreciations, are as follows:

Papaya: Multitunnel greenhouse described above in Section 2.2.

Long-cycle horticultural crops: Almería type "raspa y amagado" greenhouse with $6.00 \mathrm{~m}$ ridge height, $5.00 \mathrm{~m}$ gutter height (amagado), and $4.70 \mathrm{~m}$ wall height [8].

Short cycle horticultural crops: Almería type "raspa y amagado" greenhouse, with $4.50 \mathrm{~m}$ ridge height, $3.50 \mathrm{~m}$ gutter height (amagado), and $3.00 \mathrm{~m}$ wall height. These are the dimensions of the "fashionable greenhouse" obtained by Valera et. al. [8]

The rest of infrastructures of production, climate control, and irrigation systems were the same in the different cases analyzed. The energy costs in the papaya cultivation and in the horticultural alternatives were the same in this study. The greenhouses were naturally ventilated without any heating system.

The amount of the total revenues from papaya cultivation was obtained from the real value in euros of the production which was sold during the corresponding field trial. In the case of horticultural alternatives (Horticultural 1 to Horticultural 5), the value of the total revenues was calculated by multiplying the average yield $\left(\mathrm{kg} / \mathrm{m}^{2}\right)$ of each crop by the corresponding average campaign price $(€ / \mathrm{kg})$ (see Table 2 and Appendix A, Table A1) [17].

With respect to current expenditure, technical assessment was the same for the eight crops studied. Soil preparation was adjusted depending on the cycle length, 6,12 , or 30 months. The covering and structure depend on the type of greenhouse used and the size of the plastic covering, which also depends on the greenhouse size and the difference of labour costs to replace the greenhouse plastic which, in turn, and also depends on the structure and height of the greenhouse covering. For seeds and seedling production, the data were obtained according to the costs of each year.

In the case of water, fertilizers, phytosanitary products, labor costs, stakes, auxiliary insects, and management of crop residues, the guidelines marked individually for each crop and cycle by Toresano and Camacho [30] were followed. It is important to highlight the economic percentage weight that labor costs have within the current costs, once the work units were assessed (Table 3).

Table 3. Economic percentage weight of labor on current expenses of horticultural crops that occur in the southeast of Spain (Toresano and Camacho) [30].

\begin{tabular}{ccccccccc}
\hline Culture & Tomato & Sweet Pepper & Cucumber & Aubergine & Courgette & Green Bean & Melon & Watermelon \\
\hline Percentage & 52.66 & 47.32 & 45.40 & 52.07 & 86.44 & 42.00 & 22.33 & 21.19 \\
\hline
\end{tabular}

\section{Results and Discussion}

Based on the obtained yield, the harvest of papaya (after assessing the yield parameters, average fruit weight, and soluble solids in ${ }^{\circ}$ Brix) is appropriate to put papaya on the European market, since they have similar characteristics to those that are being imported to Europe from other continents.

\subsection{Total Yield of Papaya}

In the first season, 81 harvests were carried out between weeks 41 in 2016 and 31 in 2017. In the second season, 68 harvests were carried out between weeks 35 in 2017 and 25 in 2018. The total yield was $27.63 \mathrm{~kg} \cdot \mathrm{m}^{-2}$ (see Appendix A, Table A2).

The results obtained in this experiment of $276.3 \mathrm{t}_{\mathrm{h}} \mathrm{ha}^{-1}$, are higher than those obtained in studies from Costa Rica by Guzmán Díaz [31], which varied between 40 and 70 t·ha ${ }^{-1}$, and Jiménez Díaz [32], 
who obtained 89 tha ${ }^{-1}$ in a three-year cycle. In Mexico, Escamilla et al. [33] conducted an experiment to study yield of cultivarMaradol papaya and obtained 27.94 t.ha ${ }^{-1}$. In India Singh et al. [34] reported yields between 65 and $93 \mathrm{t} \cdot \mathrm{ha}^{-1}$. In other experiments in India, Jeyakumar et al. [35], reported yields between 139.3 and $184.9 \mathrm{t} \cdot \mathrm{ha}^{-1}$. and Bhalerao et al. [36] obtained between 51.83 and $80.76 \mathrm{t} \cdot \mathrm{ha}^{-1}$. Migliaccio et al. [37] carried out an experiment in Florida (USA) and obtained yields between 152 and 193 t.ha ${ }^{-1}$.

The difference in total production of papaya produced in Almería with respect to total production for other countries mentioned, is due to the production system. In effect, in Almería the papaya is cultivated under greenhouses while in the rest of the countries, this is an open field cultivation.

\subsection{Average Fruit Weight (AFW) of Papaya}

The fruits harvested in the second season weighed more than those obtained in the first season.

These data are consistent with those obtained by Pérez Hernández [23], in an experiment conducted with 10 different varieties, where the fruit harvested in the second season weighed more than those obtained in the first season.

The weight obtained in the fruits has an acceptable demand in the European market. The weight of the Intenzza fruit in this experiment had the size G (801-1100 g) and H (1101-1500 g), described in the International FAO (Food and Agriculture Organization of the United Nations) Standards for papaya cultivation [38].

\subsection{Number of Fruits per Plant}

The number of fruits per plant in the second season was lower. There is a relationship between fruit size and number of fruits per plant.

\subsection{Total Soluble Solids}

The analysis of total soluble solids was made for the ${ }^{\circ}$ Brix average and for the maximum ${ }^{\circ}$ Brix in fruits. The values obtained throughout the harvest time varied between 10.00 and $10.30^{\circ} \mathrm{Brix}$.

These values were similar to those obtained by Pérez Hernández [23] for the Intenzza variety grown in the Canary Islands. The values are also similar to the results obtained by Santamaría et al. [39] in Costa Rica. The data obtained in the experiment permitted the sale of papaya fruits in different European countries.

\subsection{Comparative of Results: Horticultural Alternatives Versus Papaya Cultivation}

After the analysis of the structure of revenues and costs of the main combinations of horticultural crops in the southeast of Spain, a comparison of the economic yields was made with those obtained by papaya cultivation as described above (see Tables A2-A7 in the Supplementary Material, Appendix A). In the case of papaya cultivation, the real costs and revenues were taken into account, whereas in the case of the different horticultural alternatives, the production data and prices used were published by official bodies $[17,40]$. Furthermore, the detail of horticultural costs, attributable to each alternative, comes from the cost analysis updated by Toresano and Camacho for Agroseguros, S.A.-Spain [30]. The results of the comparison of papaya crop with five crops that are usually cultivated in the Province of Almería are detailed and represented in Tables A2-A7 (see the Supplementary Material, Appendix A). The data of Table 4 are obtained from Tables A2-A7 and represent a resume of the comparison for the five crops. 
Table 4. Structure of revenues and costs per hectare of five horticultural alternative crops versus papaya cultivation, analyzed from February 2016 to July 2018.

\begin{tabular}{|c|c|c|c|c|c|c|}
\hline $\begin{array}{l}\text { Comparison. } \\
\text { Feb } 2016 \text { to July } 2018\end{array}$ & $\begin{array}{c}\text { Horticultural } \\
\text { Alternative } \\
\mathbf{1}\end{array}$ & $\begin{array}{c}\text { Horticultural } \\
\text { Alternative } \\
2\end{array}$ & $\begin{array}{c}\text { Horticultural } \\
\text { Alternative } \\
3\end{array}$ & $\begin{array}{c}\text { Horticultural } \\
\text { Alternative } \\
4\end{array}$ & $\begin{array}{c}\text { Horticultural } \\
\text { Alternative } \\
5\end{array}$ & $\begin{array}{l}\text { Papaya } \\
\text { Cultivation }\end{array}$ \\
\hline Total annual revenues $(€)$ & 193,805 & 203,845 & 188,498 & 158,765 & 281,560 & 248,013 \\
\hline Total variable cost $(€)$ & 177,390 & 191,244 & 179,599 & 175,953 & 194,971 & 135,618 \\
\hline Technical assessment $(€)$ & 772 & 772 & 772 & 772 & 772 & 772 \\
\hline Soil preparation $(€)$ & 19,458 & 19,458 & 19,458 & 19,458 & 11,575 & 3839 \\
\hline Covering and structure $(€)$ & 11,846 & 11,846 & 11,846 & 11,846 & 11,846 & 12,297 \\
\hline Seeds and seedling production $(€)$ & 17,983 & 22,588 & 25,630 & 18,741 & 14,689 & 13,500 \\
\hline Growing and development until 1st inflorescence $(€)$ & 41,947 & 35,401 & 34,958 & 43,591 & 32,898 & 33,131 \\
\hline Flowering periods until 1st harvesting season $(€)$ & 25,779 & 33,679 & 25,862 & 18,771 & 31,380 & 37,570 \\
\hline From the 1st harvesting season until the end of the cultivation $(€)$ & 59,605 & 67,499 & 61,073 & 62,772 & 91,811 & 34,510 \\
\hline Total fixed costs $(€)$ & 49,052 & 49,052 & 49,052 & 49,052 & 53,693 & 54,859 \\
\hline Soil maintenance $(€)$ & 5140 & 5140 & 5140 & 5140 & 5140 & 5125 \\
\hline Covering and structure $(€)$ & 10,287 & 10,287 & 10,287 & 10,287 & 10,287 & 10,257 \\
\hline Energy and fixed supplies $(€)$ & 4063 & 4063 & 4063 & 4063 & 4063 & 4051 \\
\hline Insurance, management, and financial services $(€)$ & 8947 & 8947 & 8947 & 8947 & 8947 & 8920 \\
\hline Equipment and irrigation system $(€)$ & 20,615 & 20,615 & 20,615 & 20,615 & 25,256 & 26,506 \\
\hline Total cost $(€)$ & 226,443 & 240,296 & 228,651 & 225,005 & 248,664 & 190,477 \\
\hline Net profit before taxes $(€)$ & $-32,638$ & $-36,451$ & $-40,153$ & $-66,240$ & 32,896 & 57,535 \\
\hline
\end{tabular}

Source: Own elaboration from a field trial (papaya), Toresano and Camacho [30] and Annual Report of the Regional Department of Agriculture, Rural Development and Fisheries [17]. 
Table 4 shows the profit and loss account of each of the alternatives that are compared, that is, the five horticultural combinations with papaya cultivation. In the case of papaya, the revenues that were calculated in the experiment were those received by the sale of this fruit. The data are obtained from Table A2 (see Supplementary Material, Appendix A). All the papaya fruits coming from the Experimental Plot of the Foundation University of Almería-Anecoop were put on the market through a company operating in the region, which is a specialist in introducing new fruits to European markets. This company grew 10 papaya hectares on its own plots of land and on other plots belonging to its associates. In all the cases, the comparisons were made for the same period, from February 2016 to July 2018.

The data of total annual revenues for each cultivation in this table are provided in the Supplementary Material-Tables A2-A7 in Appendix A. To have a global visualization of the comparison between the five horticultural alternatives and papaya crop, the total annual revenues, the total costs, and the net profit (before taxes) are represented in Figure 4 for each case. The data were obtained from Table 4. Figure 4 shows the comparison between papaya cultivation in southeast Spain with the different proposed horticultural alternatives. In this figure, four out of the five combinations of horticultural crops generate losses within the period analyzed (February 2016 to July 2018) and only the combination called "Horticultural 5" gives profits.

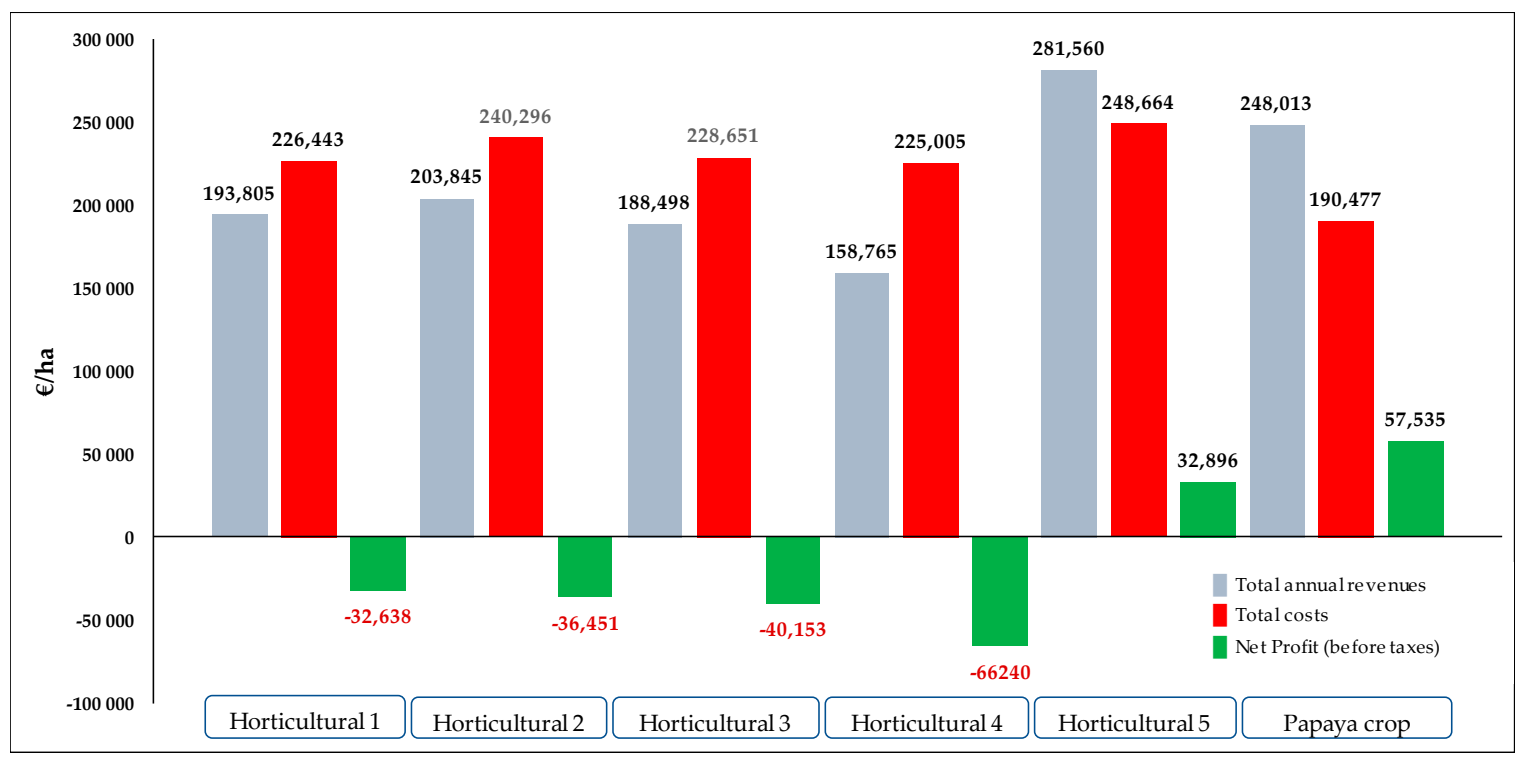

Figure 4. Comparison between the economic results ( $€ /$ ha) of the proposed horticultural alternatives and the cultivation of the papaya in a 30-month cycle (2016-2018). Total annual revenues ( $)$; Total costs (घ); Net Profit (before taxes) (口). Own elaboration.

The question that needs to be asked is how can this horticultural production model be maintained, especially in the "Horticultural 1 to Horticultural 4" combinations? As certain studies had anticipated [41], the answer must be sought in the structure of the revenue statements of each farm and not from a business logic, profit maximization, but in a way to subsist in a mature sector. In this sense, there are two accounting entries that are not assessed in terms of opportunity costs by the owners of the farming business. These are labor costs and annual depreciation costs:

1. There are some studies that place labor costs between $25 \%$ and $40 \%$ of the annual costs of a farming business under greenhouses [42,43]. In this sense, the field study that was carried out by Valera et al. [8] showed that the owner of the farming business, together with their staff, is another worker. Therefore, when there are losses, as described in the combinations "Horticultural 1 to Horticultural 4", the owner renounces his remuneration as owner of the means of production because they tend to reduce staff numbers and, together with their family, take roles which, during favorable economic conditions, would be filled with employed workers. 
2. The annual depreciation cost of the greenhouse structure, the irrigation system and pools, represents the main part of the fixed costs of the farming business. According to Calatrava and Villa [44], the fixed costs of a greenhouse used for horticulture varies from 1 to $1.5 € / \mathrm{m}^{2}$. This result is in accordance with our calculations per hectare and cycle (see "Total fixed costs $(€)$ ", in Tables A2-A7, in Supplementary Material, Appendix A). In this case, the depreciation cost can reach $50 \%$ of the total fixed costs, from 4000 to 5000 Euros per hectare and cycle. In the case of producers with lower indebtedness and that have already paid for the farming business, they could have these amounts available because they would not be obliged to depreciate yearly. Considering the average area of the farming business in Almería, 23,508 $\mathrm{m}^{2}$ [45], the depreciation costs of the greenhouse structures, irrigation systems and pools, would be higher than the costs stated in this article. Furthermore, the level of subsidies that the Almería intensive horticulture receives is low in relation to its size [8] and as has already happened in other productive sectors of the province. In the foreseeable future the subsidies should be reduced [46].

3. Finally, we calculated the accumulated net profit before taxes for each comparison of the horticultural alternatives and papaya crop during the period of 30 months (February 2016 to July 2018), time used for the trial with the papaya crop. Figure 5 represents the visualization of the accumulated monthly Net Profit before taxes (NPbt) for the most profitable crop (Horticultural 5 and the papaya cultivation, see Tables A2 and A7) during the period of the trial (30 months). In both cases, there was a positive net profit. Monthly, the calculated NPbt in each alternative is added the NPbt of the last month and cumulated, until the end of the period. The "Horticultural 5" contains a cycle of courgette cultivation and two cycles of tomato cultivation. Analyzing Figure 5, it can be highlighted that the farmers which choose the papaya cultivation should be conscious that they must have enough liquidity to maintain their business for 11 months (March 2017, in Figure 5). At this moment, the NPbt is positive. In the case of Horticultural 5, after 3 months (May 2016), the farmer can recover part of his investment, althought the cumulative NPbt is still negative. Most of the time, farmers prefer horticultural crops with short cycle, of 6 months, for which they begin to receive revenues for the sale of their products and to improve the cumulative NPbt, $40-45$ days after sowing.

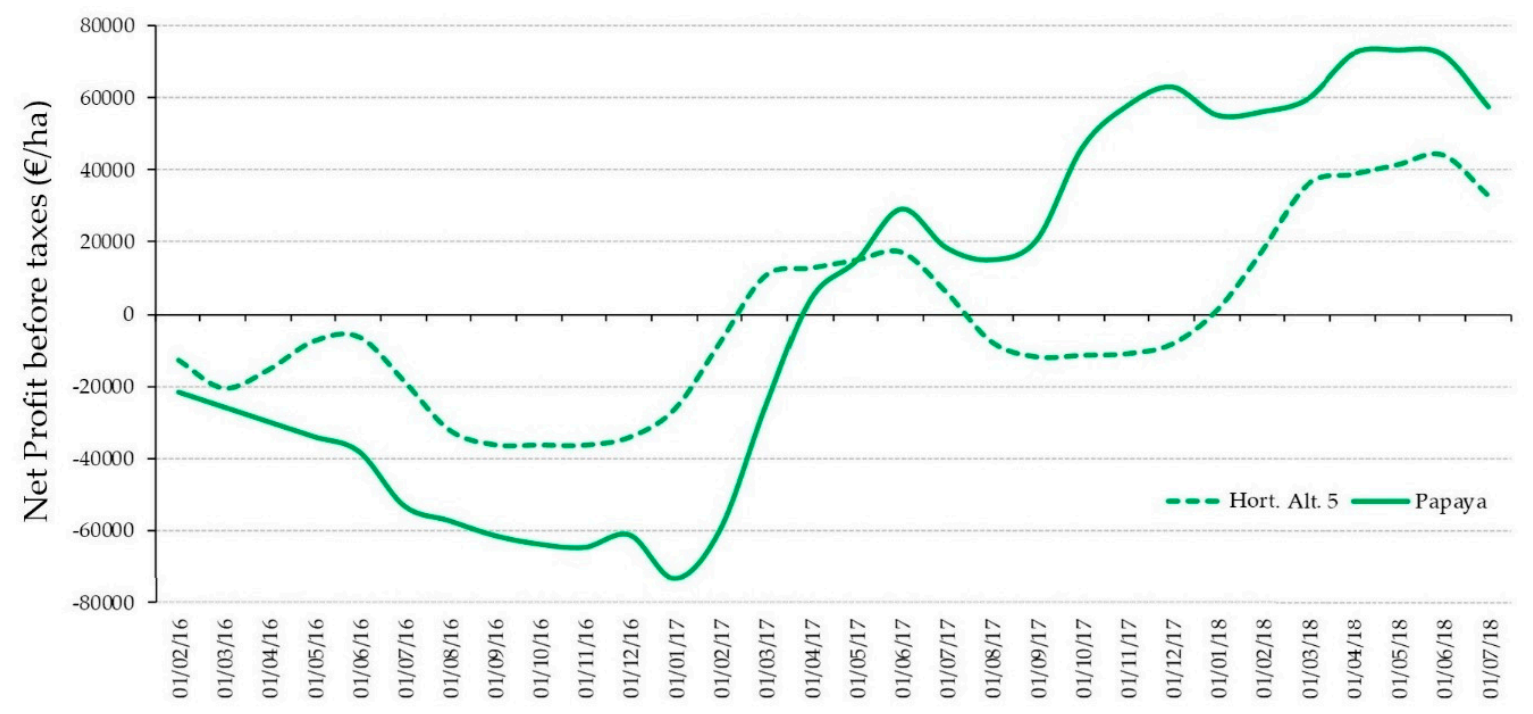

Figure 5. Monthly evolution of the accumulated Net Profit before taxes (NPbt) for Horticultural alternative $5(---)$ versus papaya cultivation $(-)(€ /$ ha) during the trial period (February 2016 to July 2018). Own elaboration $[17,30]$.

\section{Conclusions}

After analyzing the development of the areas and production of the main horticultural crops in southeast Spain, as well as the evolution of the average prices from 2009 to 2018, there are evident 
signs that the horticultural production model in Almería is at a mature stage. In addition to this, there is also an assessment of the alternative of papaya crops grown under greenhouses. After making a comparison of papaya crop with five crops that are usually cultivated in the Province of Almería, it can be observed that only one horticultural alternative gives positive results, from February 2016 to July 2018. For each one of those crops, the cultural system is very particular, and this is the reason why the comparison must be taken in the context of the province of Almería. For the cultivation of papaya, there was only one plantation (from February 2016 to July 2018, 30 months), and in the alternative five, three crops were planted (one cycle of courgette and two cycles of tomato), thus, to achieve a planting period similar to the papaya crop.

A detailed analysis of the profit and loss account for each of the horticultural alternatives allows a relationship to be drawn between the good results of the season with high sale prices, compared with the average of previous seasons in 2017, the year with best economic result for the horticultural production model in Almería. In 2017, an average price of $0.68 € \cdot \mathrm{kg}^{-1}$ was registered compared with the range from 0.50 to $0.59 € \cdot \mathrm{kg}^{-1}$ that was registered in the period 2009-2018. The producers of long-cycle tomatoes are the only ones who achieve reduction in their variable costs (in the phases from the "seed to the seedling in nursery" and the phase from "flowering to first harvesting season"), making the harvest period more continuous and, therefore, obtaining revenues from the sales of the horticultural commodities.

With the results of this work, it is demonstrated that papaya can be one of the crops for the Province of Almería to extend the range of products offered to the Northern European market. The papaya cultivation under greenhouses in this region is feasible, with higher yield obtained than in other countries, with local mature commercial channels which have the how-know to sell exotic commodities complying with the European marketing standards. The cultivation of this fruit under greenhouses in Almería can be a rentable and commercial activity for farmers.

Author Contributions: Conceptualization, F.C.F. and L.J.B.-U.; Methodology, F.C.-F. and L.J.B.-U.; Investigation, M.N.H.; Resources, F.C.F. and A.N.V.; Data Curation, M.N.H., F.C.-F. and L.J.B.-U.; Writing-Original Draft Preparation, M.N.H., F.C.-F. and L.J.B.-U.; Writing-Review \& Editing, M.N.H., F.C.-F. and L.J.B.-U.; Visualization, M.N.H. and L.J.B.-U.; Supervision, F.C.-F. and L.J.B.-U.; Project Administration, F.C.-F. and A.N.-V.; Funding Acquisition, F.C.-F., A.N.-V. and L.J.B.-U.

Funding: This research was funded by the University of Almería (AGR-200) and Vitalplant, nursery. Almería, Spain.

Acknowledgments: We thank the UAL-ANECOOP Foundation Experimental Research Center and Vitalplant nursery for their collaboration and assistance during the development of this study. The authors gratefully acknowledge the support provided by the staff of the UAL-ANECOOP Foundation Experimental Research Center. The authors would like to thank Rocío Guerrero Moya for her help in the field measurements.

Conflicts of Interest: The authors declare no conflict of interest.

\section{Appendix A}

Table A1. Area, production, and price of horticultural crops in years 2016-2018.

\begin{tabular}{|c|c|c|c|c|c|c|c|c|c|}
\hline \multirow{2}{*}{ Crop } & \multicolumn{3}{|c|}{2016} & \multicolumn{3}{|c|}{2017} & \multicolumn{3}{|c|}{2018} \\
\hline & $\begin{array}{l}\text { Area } \\
\text { (ha) }\end{array}$ & $\begin{array}{l}\text { Production } \\
(t)\end{array}$ & $\begin{array}{c}\text { Price } \\
\left(€ \cdot \mathrm{kg}^{-1}\right)\end{array}$ & $\begin{array}{c}\text { Area } \\
\text { (ha) }\end{array}$ & $\begin{array}{l}\text { Production } \\
(t)\end{array}$ & $\begin{array}{c}\text { Price } \\
\left(€ \cdot \mathrm{kg}^{-1}\right)\end{array}$ & $\begin{array}{c}\text { Area } \\
\text { (ha) }\end{array}$ & $\begin{array}{l}\text { Production } \\
\text { (t) }\end{array}$ & $\begin{array}{c}\text { Price } \\
\left(\epsilon \cdot \mathrm{kg}^{-1}\right)\end{array}$ \\
\hline Watermelon & 8590 & 532,288 & 0.318 & 8940 & 558,223 & 0.327 & 9860 & 512,742 & 0.407 \\
\hline Melon & 2467 & 96,417 & 0.470 & 2220 & 93,527 & 0.448 & 2290 & 91,656 & 0.535 \\
\hline Courgette & 7630 & 434,195 & 0.489 & 7970 & 448,975 & 0.681 & 7860 & 456,045 & 0.555 \\
\hline Cucumber & 5026 & 438,870 & 0.418 & 4980 & 422,214 & 0.640 & 5099 & 443,604 & 0.501 \\
\hline Aubergine & 2300 & 184,161 & 0.371 & 2,150 & 168,046 & 0.728 & 2,209 & 181,130 & 0.513 \\
\hline Tomato & 10,940 & $1,107,706$ & 0.527 & 10,220 & $1,008,867$ & 0.714 & 10,380 & 996,254 & 0.621 \\
\hline Sweet pepper & 9491 & 665,922 & 0.824 & 10,310 & 694,402 & 0.908 & 10,181 & 732,989 & 0.755 \\
\hline Green bean & 1340 & 26,453 & 1.455 & 1030 & 21,001 & 1.747 & 510 & 10,224 & 1.584 \\
\hline
\end{tabular}

Own elaboration made with data provided by Andalusian Regional Government (Almería, Spain) [17,30]. 
Table A2. Revenues and expenses per hectare imputed to the papaya cultivation in a 30-month cycle (2016-2018).

\begin{tabular}{|c|c|c|c|c|c|c|}
\hline \multirow{2}{*}{ Papaya Cultivation } & Papaya & Papaya & Papaya & Papaya & Papaya & Total \\
\hline & $\begin{array}{c}\text { February } 2016 \\
\text { to July } 2016\end{array}$ & $\begin{array}{c}\text { August } 2016 \text { to } \\
\text { January } 2017\end{array}$ & $\begin{array}{c}\text { February } 2017 \\
\text { to July } 2017\end{array}$ & $\begin{array}{c}\text { August } 2017 \text { to } \\
\text { January } 2018\end{array}$ & $\begin{array}{c}\text { February } 2018 \\
\text { to July } 2018\end{array}$ & $\begin{array}{c}\text { February } 2016 \\
\text { to July } 2018\end{array}$ \\
\hline Total annual revenues $(€)$ & - & 16,874 & 130,268 & 67,523 & 33,347 & 248,013 \\
\hline Yield $\left({\left.\mathrm{kg} \cdot \mathrm{ha}^{-1}\right)}^{-1}\right.$ & - & 12,532 & 127,809 & 85,727 & 50,213 & 276,282 \\
\hline Average price $\left(€ \cdot \mathrm{kg}^{-1}\right)$ & & 1.326 & 1.013 & 0.784 & 0.665 & 0.893 \\
\hline Total variable cost $(€)$ & 42,022 & 26,162 & 27,645 & 19,889 & 19,900 & 135,618 \\
\hline Technical assessment $(€)$ & 152 & 152 & 155 & 155 & 158 & 772 \\
\hline Soil preparation $(€)$ & 3839 & - & - & - & - & 3839 \\
\hline Covering and structure $(€)$ & 2443 & 2443 & 2444 & 2480 & 2487 & 12,297 \\
\hline Seeds and seedling production $(€)$ & 13,500 & - & - & - & - & 13,500 \\
\hline Growing and development until $1^{\text {st }}$ inflorescence $(€)$ & 22,087 & 11,044 & - & - & - & 33,131 \\
\hline Flowering periods until $1^{\text {st }}$ harvesting season $(€)$ & - & 12,523 & 25,047 & - & - & 37,570 \\
\hline From the $1^{\text {st }}$ harvesting season until the end of the cultivation $(€)$ & - & - & - & 17,255 & 17,255 & 34,510 \\
\hline Total fixed costs $(€)$ & 10,912 & 10,912 & 10,996 & 10,912 & 11,127 & 54,859 \\
\hline Soil maintenance $(€)$ & 1014 & 1014 & 1029 & 1014 & 1053 & 5125 \\
\hline Covering and structure $(€)$ & 2030 & 2030 & 2060 & 2030 & 2108 & 10,257 \\
\hline Energy and fixed supplies $(€)$ & 802 & 802 & 814 & 802 & 832 & 4051 \\
\hline Insurance, management, and financial services $(€)$ & 1765 & 1765 & 1792 & 1765 & 1833 & 8920 \\
\hline Equipment and irrigation system $(€)$ & 5301 & 5301 & 5301 & 5301 & 5301 & 26,506 \\
\hline Total cost $(€)$ & 52,934 & 37,074 & 38,641 & 30,801 & 31,027 & 190,477 \\
\hline Net profit before taxes $(€)$ & $-52,934$ & $-20,201$ & 91,627 & 36,722 & 2320 & 57,535 \\
\hline
\end{tabular}


Table A3. Revenues and expenses per hectare imputed to the cultivation of the horticultural alternative 1 in a 30-month cycle (2016-2018).

\begin{tabular}{|c|c|c|c|c|c|c|}
\hline \multirow[b]{2}{*}{ Horticultural Alternative 1} & Watermelon & Tomato & Courgette & Sweet Pepper & Watermelon & Total \\
\hline & $\begin{array}{c}\text { February } 2016 \\
\text { to July } 2016\end{array}$ & $\begin{array}{l}\text { August } 2016 \text { to } \\
\text { January } 2017\end{array}$ & $\begin{array}{c}\text { February } 2017 \\
\text { to July } 2017\end{array}$ & $\begin{array}{c}\text { August } 2017 \text { to } \\
\text { January } 2018\end{array}$ & $\begin{array}{c}\text { February } 2018 \\
\text { to July } 2018\end{array}$ & $\begin{array}{c}\text { February } 2016 \\
\text { to July } 2018\end{array}$ \\
\hline Total annual revenues $(€)$ & 19,716 & 53,385 & 38,340 & 61,199 & 21,164 & 193,805 \\
\hline Yield $\left(\mathrm{kg} \cdot \mathrm{ha}^{-1}\right)$ & 62,000 & 101,300 & 56,300 & 67,400 & 52,000 & \\
\hline Average price $\left(€ \cdot \mathrm{kg}^{-1}\right)$ & 0.318 & 0.527 & 0.681 & 0.908 & 0.407 & \\
\hline Total variable cost $(€)$ & 18,532 & 52,092 & 36,406 & 51,117 & 19,243 & 177,390 \\
\hline Technical assessment $(€)$ & 152 & 152 & 155 & 155 & 158 & 772 \\
\hline Soil preparation $(€)$ & 3839 & 3839 & 3897 & 3897 & 3986 & 19,458 \\
\hline Covering and structure $(€)$ & 2337 & 2337 & 2372 & 2372 & 2427 & 11,846 \\
\hline Seeds and seedling production $(€)$ & 1993 & 5639 & 1277 & 7005 & 2070 & 17,983 \\
\hline Growing and development until $1^{\text {st }}$ inflorescence $(€)$ & 3173 & 7385 & 14,942 & 13,151 & 3295 & 41,947 \\
\hline Flowering periods until $1^{\text {st }}$ harvesting season $(€)$ & - & 15,573 & - & 10,206 & - & 25,779 \\
\hline From the $1^{\text {st }}$ harvesting season until the end of the cultivation $(€)$ & 7037 & 17,166 & 13,763 & 14,332 & 7307 & 59,605 \\
\hline Total fixed costs $(€)$ & 9678 & 9678 & 9823 & 9823 & 10,049 & 49,052 \\
\hline Soil maintenance $(€)$ & 1014 & 1014 & 1029 & 1029 & 1053 & 5140 \\
\hline Covering and structure $(€)$ & 2030 & 2030 & 2060 & 2060 & 2108 & 10,287 \\
\hline Energy and fixed supplies $(€)$ & 802 & 802 & 814 & 814 & 832 & 4063 \\
\hline Insurance, management, and financial services $(€)$ & 1765 & 1765 & 1792 & 1792 & 1833 & 8947 \\
\hline Equipment and irrigation system $(€)$ & 4067 & 4067 & 4128 & 4128 & 4223 & 20,615 \\
\hline Total cost $(€)$ & 28,211 & 61,770 & 46,230 & 60,940 & 29,292 & 226,443 \\
\hline Net profit before taxes $(€)$ & -8495 & -8385 & -7889 & 259 & -8128 & $-32,638$ \\
\hline
\end{tabular}

Own elaboration made with revenue data provided by Andalusian Regional Government [17,30]. 
Table A4. Revenues and expenses per hectare imputed to the cultivation of the horticultural alternative 2 in a 30-month cycle (2016-2018).

\begin{tabular}{|c|c|c|c|c|c|c|}
\hline \multirow[b]{2}{*}{ Horticultural Alternative 2} & Tomato & Cucumber & Aubergine & Green Bean & Melon & Total \\
\hline & $\begin{array}{c}\text { February } 2016 \\
\text { to July } 2016\end{array}$ & $\begin{array}{l}\text { August } 2016 \text { to } \\
\text { January } 2017\end{array}$ & $\begin{array}{c}\text { February } 2017 \\
\text { to July } 2017\end{array}$ & $\begin{array}{c}\text { August } 2017 \text { to } \\
\text { January } 2018\end{array}$ & $\begin{array}{c}\text { February } 2018 \\
\text { to July } 2018\end{array}$ & $\begin{array}{c}\text { February } 2016 \\
\text { to July } 2018\end{array}$ \\
\hline Total annual revenues $(€)$ & 53,385 & 36,491 & 56,930 & 35,639 & 21,400 & 203,845 \\
\hline Yield $\left(\mathrm{kg} \cdot \mathrm{ha}^{-1}\right)$ & 101,300 & 87,300 & 78,200 & 20,400 & 40,000 & \\
\hline Average price $\left(€ \cdot \mathrm{kg}^{-1}\right)$ & 0.527 & 0.418 & 0.728 & 1.747 & 0.535 & \\
\hline Total variable cost $(€)$ & 52,092 & 42,301 & 41,681 & 25,851 & 29,318 & 191,244 \\
\hline Technical assessment $(€)$ & 152 & 152 & 155 & 155 & 158 & 772 \\
\hline Soil preparation $(€)$ & 3839 & 3839 & 3897 & 3897 & 3986 & 19,458 \\
\hline Covering and structure $(€)$ & 2337 & 2337 & 2372 & 2372 & 2427 & 11,846 \\
\hline Seeds and seedling production $(€)$ & 5639 & 6901 & 2984 & 1470 & 5594 & 22,588 \\
\hline Growing and development until $1^{\text {st }}$ inflorescence $(€)$ & 7385 & 8472 & 6907 & 6889 & 5748 & 35,401 \\
\hline Flowering periods until $1^{\text {st }}$ harvesting season $(€)$ & 15,573 & 7063 & 8694 & 2349 & - & 33,679 \\
\hline From the $1^{\text {st }}$ harvesting season until the end of the cultivation $(€)$ & 17,166 & 13,536 & 16,673 & 8720 & 11,404 & 67,499 \\
\hline Total fixed costs $(€)$ & 9678 & 9678 & 9823 & 9823 & 10,049 & 49,052 \\
\hline Soil maintenance $(€)$ & 1014 & 1014 & 1029 & 1029 & 1053 & 5140 \\
\hline Covering and structure $(€)$ & 2030 & 2030 & 2060 & 2060 & 2108 & 10,287 \\
\hline Energy and fixed supplies $(€)$ & 802 & 802 & 814 & 814 & 832 & 4063 \\
\hline Insurance, management, and financial services $(€)$ & 1765 & 1765 & 1792 & 1792 & 1833 & 8947 \\
\hline Equipment and irrigation system (€) & 4067 & 4067 & 4128 & 4128 & 4223 & 20,615 \\
\hline Total cost $(€)$ & 61,770 & 51,980 & 51,505 & 35,674 & 39,367 & 240,296 \\
\hline Net profit before taxes $(€)$ & -8385 & $-15,488$ & 5425 & -36 & $-17,967$ & $-36,451$ \\
\hline
\end{tabular}

Own elaboration made with revenue data provided by Andalusian Regional Government [17,30]. 
Table A5. Revenues and expenses per hectare imputed to the cultivation of the horticultural alternative 3 in a 30-month cycle (2016-2018).

\begin{tabular}{|c|c|c|c|c|c|c|}
\hline \multirow[b]{2}{*}{ Horticultural Alternative 3} & Melon & Sweet Pepper & Watermelon & Tomato & Melon & Total \\
\hline & $\begin{array}{c}\text { February } 2016 \\
\text { to July } 2016\end{array}$ & $\begin{array}{l}\text { August } 2016 \text { to } \\
\text { January } 2017\end{array}$ & $\begin{array}{c}\text { February } 2017 \\
\text { to July } 2017\end{array}$ & $\begin{array}{c}\text { August } 2017 \text { to } \\
\text { January } 2018\end{array}$ & $\begin{array}{c}\text { February } 2018 \\
\text { to July } 2018\end{array}$ & $\begin{array}{c}\text { February } 2016 \\
\text { to July } 2018\end{array}$ \\
\hline Total annual revenues $(€)$ & 18,377 & 57,845 & 20,405 & 70,472 & 21,400 & 188,498 \\
\hline Yield $\left(\mathrm{kg} \cdot \mathrm{ha}^{-1}\right)$ & 39,100 & 70,200 & 62,400 & 98,700 & 40,000 & \\
\hline Average price $\left(€ \cdot \mathrm{kg}^{-1}\right)$ & 0.470 & 0.824 & 0.327 & 0.714 & 0.535 & \\
\hline Total variable cost $(€)$ & 28,235 & 50,361 & 18,810 & 52,873 & 29,318 & 179,599 \\
\hline Technical assessment $(€)$ & 152 & 152 & 155 & 155 & 158 & 772 \\
\hline Soil preparation $(€)$ & 3839 & 3839 & 3897 & 3897 & 3986 & 19,458 \\
\hline Covering and structure $(€)$ & 2337 & 2337 & 2372 & 2372 & 2427 & 11,846 \\
\hline Seeds and seedling production $(€)$ & 5388 & 6901 & 2023 & 5723 & 5594 & 25,630 \\
\hline Growing and development until $1^{\text {st }}$ inflorescence $(€)$ & 5536 & 12,957 & 3221 & 7496 & 5748 & 34,958 \\
\hline Flowering periods until $1^{\text {st }}$ harvesting season $(€)$ & - & 10,055 & - & 15,807 & - & 25,862 \\
\hline From the $1^{\text {st }}$ harvesting season until the end of the cultivation $(€)$ & 10,983 & 14,120 & 7143 & 17,424 & 11,404 & 61,073 \\
\hline Total fixed costs $(€)$ & 9678 & 9678 & 9823 & 9823 & 10,049 & 49,052 \\
\hline Soil maintenance $(€)$ & 1014 & 1014 & 1029 & 1029 & 1053 & 5140 \\
\hline Covering and structure $(€)$ & 2030 & 2030 & 2060 & 2060 & 2108 & 10,287 \\
\hline Energy and fixed supplies $(€)$ & 802 & 802 & 814 & 814 & 832 & 4063 \\
\hline Insurance, management, and financial services $(€)$ & 1765 & 1765 & 1792 & 1792 & 1833 & 8947 \\
\hline Equipment and irrigation system $(€)$ & 4067 & 4067 & 4128 & 4128 & 4223 & 20,615 \\
\hline Total cost $(€)$ & 37,914 & 60,040 & 28,634 & 62,697 & 39,367 & 228,651 \\
\hline Net profit before taxes $(€)$ & $-19,537$ & -2195 & -8229 & 7775 & $-17,967$ & $-40,153$ \\
\hline
\end{tabular}

Own elaboration made with revenue data provided by Andalusian Regional Government [17,30]. 
Table A6. Revenues and expenses per hectare imputed to the cultivation of the horticultural alternative 4 in a 30-month cycle (2016-2018).

\begin{tabular}{|c|c|c|c|c|c|c|}
\hline \multirow[b]{2}{*}{ Horticultural Alternative 4} & Courgette & Aubergine & Melon & Sweet Peper & Watermelon & Total \\
\hline & $\begin{array}{c}\text { February } 2016 \\
\text { to July } 2016\end{array}$ & $\begin{array}{l}\text { August } 2016 \text { to } \\
\text { January } 2017\end{array}$ & $\begin{array}{c}\text { February } 2017 \\
\text { to July } 2017\end{array}$ & $\begin{array}{c}\text { August } 2017 \text { to } \\
\text { January } 2018\end{array}$ & $\begin{array}{c}\text { February } 2018 \\
\text { to July } 2018\end{array}$ & $\begin{array}{c}\text { February } 2016 \\
\text { to July } 2018\end{array}$ \\
\hline Total annual revenues $(€)$ & 27,824 & 29,717 & 18,861 & 61,199 & 21,164 & 158,765 \\
\hline Yield $\left(\mathrm{kg} \cdot \mathrm{ha}^{-1}\right)$ & 56,900 & 80,100 & 42,100 & 67,400 & 52,000 & \\
\hline Average price $\left(€ \cdot \mathrm{kg}^{-1}\right)$ & 0.489 & 0.371 & 0.448 & 0.908 & 0.407 & \\
\hline Total variable cost $(€)$ & 35,868 & 41,065 & 28,659 & 51,117 & 19,243 & 175,953 \\
\hline Technical assessment $(€)$ & 152 & 152 & 155 & 155 & 158 & 772 \\
\hline Soil preparation $(€)$ & 3839 & 3839 & 3897 & 3897 & 3986 & 19,458 \\
\hline Covering and structure $(€)$ & 2337 & 2337 & 2372 & 2372 & 2427 & 11,846 \\
\hline Seeds and seedling production $(€)$ & 1258 & 2940 & 5469 & 7005 & 2070 & 18,741 \\
\hline Growing and development until $1^{\text {st }}$ inflorescence $(€)$ & 14,722 & 6805 & 5619 & 13,151 & 3295 & 43,591 \\
\hline Flowering periods until $1^{\text {st }}$ harvesting season $(€)$ & - & 8565 & - & 10,206 & - & 18,771 \\
\hline From the $1^{\text {st }}$ harvesting season until the end of the cultivation $(€)$ & 13,560 & 16,427 & 11,148 & 14,332 & 7307 & 62,772 \\
\hline Total fixed costs $(€)$ & 9678 & 9678 & 9823 & 9823 & 10,049 & 49,052 \\
\hline Soil maintenance $(€)$ & 1014 & 1014 & 1029 & 1029 & 1053 & 5140 \\
\hline Covering and structure $(€)$ & 2030 & 2030 & 2060 & 2060 & 2108 & 10,287 \\
\hline Energy and fixed supplies $(€)$ & 802 & 802 & 814 & 814 & 832 & 4063 \\
\hline Insurance, management, and financial services $(€)$ & 1765 & 1765 & 1792 & 1792 & 1833 & 8947 \\
\hline Equipment and irrigation system $(€)$ & 4067 & 4067 & 4128 & 4128 & 4223 & 20,615 \\
\hline Total cost $(€)$ & 45,546 & 50,744 & 38,482 & 60,940 & 29,292 & 225,005 \\
\hline Net profit before taxes $(€)$ & $-17,722$ & $-21,026$ & $-19,622$ & 259 & -8128 & $-66,240$ \\
\hline
\end{tabular}

Own elaboration made with revenue data provided by Andalusian Regional Government $[17,30]$. 
Table A7. Revenues and expenses per hectare imputed to the cultivation of the horticultural alternative 5 in a 30-month cycle (2016-2018).

\begin{tabular}{|c|c|c|c|c|c|c|}
\hline \multirow[b]{2}{*}{ Horticultural Alternative 5} & Courgette & Tomato & Tomato & Tomato & Tomato & Total \\
\hline & $\begin{array}{c}\text { February } 2016 \\
\text { to July } 2016\end{array}$ & $\begin{array}{l}\text { August } 2016 \text { to } \\
\text { January } 2017\end{array}$ & $\begin{array}{c}\text { February } 2017 \\
\text { to July } 2017\end{array}$ & $\begin{array}{c}\text { August } 2017 \text { to } \\
\text { January } 2018\end{array}$ & $\begin{array}{c}\text { February } 2018 \\
\text { to July } 2018\end{array}$ & $\begin{array}{c}\text { February } 2016 \\
\text { to July } 2018\end{array}$ \\
\hline Total annual revenues $(€)$ & 27,824 & 48,895 & 73,343 & 52,599 & 78,899 & 281,560 \\
\hline Yield $\left(\mathrm{kg} \cdot \mathrm{ha}^{-1}\right)$ & 56,900 & 78,800 & 118,200 & 78,800 & 118,200 & \\
\hline Average price $\left(€ \cdot \mathrm{kg}^{-1}\right)$ & 0.489 & 0.621 & 0.621 & 0.668 & 0.668 & \\
\hline Total variable cost $(€)$ & 35,868 & 45,977 & 30,156 & 46,755 & 36,214 & 194,971 \\
\hline Technical assessment $(€)$ & 152 & 152 & 155 & 155 & 158 & 772 \\
\hline Soil preparation $(€)$ & 3839 & 3839 & - & 3897 & - & 11,575 \\
\hline Covering and structure $(€)$ & 2337 & 2337 & 2372 & 2372 & 2427 & 11,846 \\
\hline Seeds and seedling production $(€)$ & 1258 & 5638 & - & 5723 & 2070 & 14,689 \\
\hline Growing and development until $1^{\text {st }}$ inflorescence $(€)$ & 14,722 & 7385 & - & 7496 & 3295 & 32,898 \\
\hline Flowering periods until $1^{\text {st }}$ harvesting season $(€)$ & - & 15,573 & - & 15,807 & - & 31,380 \\
\hline From the $1^{\text {st }}$ harvesting season until the end of the cultivation $(€)$ & 13,560 & 11,052 & 27,629 & 11,306 & 28,265 & 91,811 \\
\hline Total fixed costs $(€)$ & 10,662 & 10,662 & 10,746 & 10,746 & 10,877 & 53,693 \\
\hline Soil maintenance $(€)$ & 1014 & 1014 & 1029 & 1029 & 1053 & 5140 \\
\hline Covering and structure $(€)$ & 2030 & 2030 & 2060 & 2060 & 2108 & 10,287 \\
\hline Energy and fixed supplies $(€)$ & 802 & 802 & 814 & 814 & 832 & 4063 \\
\hline Insurance, management, and financial services $(€)$ & 1765 & 1765 & 1792 & 1792 & 1833 & 8947 \\
\hline Equipment and irrigation system $(€)$ & 5051 & 5051 & 5051 & 5051 & 5051 & 25,256 \\
\hline Total cost $(€)$ & 46,530 & 56,639 & 40,902 & 57,501 & 47,092 & 248,664 \\
\hline Net profit before taxes $(€)$ & $-18,706$ & -7743 & 32,441 & -4902 & 31,807 & 32,896 \\
\hline
\end{tabular}

Own elaboration made with revenue data provided by the Andalusian Regional Government [17,30]. 


\section{References}

1. Berbel, J. Analysis of protected cropping: An application of multiobjective programming techniques to Spanish horticulture. Eur. Rev. Agric. Eeon. 1989, 16, 203-216. [CrossRef]

2. Council Decision of 20 February 2006 on Community Strategic Guidelines for Rural Development (programming period 2007 to 2013). Available online: https:/eur-lex.europa.eu/eli/dec/2006/144(1)/oj (accessed on 12 July 2019).

3. Mosley, P. Why has export diversification been so hard to achieve in Africa? World Econ. 2018, 41, 1025-1044. [CrossRef]

4. Álvarez, A.; Corral, J. Identifying different technologies using a latent class model: Extensive versus intensive dairy farms. Eur. Rev. Agric. Econ. 2010, 37, 231-250. [CrossRef]

5. Aznar, S.J.A.; Galdeano, G.E.; Pérez, M.J.C. Intensive horticulture in Almería (Spain): A Counterpoint to Current European Rural Policy Strategies. J. Agrar. Chang. 2011, 11, 241-261. [CrossRef]

6. Fusco, G.; Miglietta, P.P.; Porrini, D. How Drought Affects Agricultural Insurance Policies: The Case of Italy. J. Sustain. Dev. 2018, 11, 1. [CrossRef]

7. Marković, T.; Kokot, Ž. Whole farm revenue insurance as a new model of risk management in agriculture. Ratarstvo i povrtarstvo 2018, 55, 22-28. [CrossRef]

8. Valera, M.D.L.; Belmonte, U.L.J.; Molina, A.F.D.; López, M.A. Greenhouse agriculture in Almería. A Comprehensive Techno-Economic Analysis. Available online: https://www.publicacionescajamar.e s/pdf/series-tematicas/economia/greenhouse-agriculture-in-almeria.pdf (accessed on 3 April 2019).

9. Testa, R.; di Trapani, A.M.; Sgroi, F.; Tudisca, S. Economic sustainability of Italian greenhouse cherry tomato. Sustainability 2014, 6, 7967-7981. [CrossRef]

10. Cellura, M.; Longo, S.; Mistretta, M. Life Cycle Assessment (LCA) of protected crops: An Italian case study. J. Clean Pro. 2012, 28, 56-62. [CrossRef]

11. Dorais, M.; Antón, A.; Montero, J.I.; Torrellas, M. Environmental assessment of demarcated bed-grown organic greenhouse tomatoes using renewable energy. Acta Hortic. 2014, 1041, 291-298. [CrossRef]

12. Antón, A.; Torrellas, M.; Núñez, M.; Sevigné, E.; Amores, M.J.; Muñoz, P.; Montero, J.I. Improvement of Agricultural Life Cycle Assessment Studies through Spatial Differentiation and New Impact Categories: Case Study on Greenhouse Tomato Production. Environ. Sci. Technol. 2014, 48, 9454-9462. [CrossRef]

13. Antón, A.; Castells, F.; Montero, J.I. Land use indicators in life cycle assessment. Case study: The environmental impact of Mediterranean greenhouses. J. Clean Pro. 2007, 15, 432-438. [CrossRef]

14. Galdeano, G.E. An inverse demand analysis with introduction of quality effects: An application to Spanish consumption of fruit and vegetables. Agric. Econ. 2005, 33, 163-177. [CrossRef]

15. Galdeano Gómez, E.; Céspedes Lorente, J.; Rodríguez Rodríguez, M. Productivity and Environmental Performance in Marketing Cooperatives: An Analysis of the Spanish Horticultural Sector. J. Agrar. Econ. 2006, 57, 479-500. [CrossRef]

16. Instituto de Estadística y Cartografía de Andalucía. Consejería de Economía y conocimiento. Base cartográfica de Andalucía. Descargas. 2019. Available online: https://www.juntadeandalucia.es/institutodeestadisticaycar tografia/bcadescargas/ (accessed on 22 April 2019).

17. Junta de Andalucía-Consejería de Agricultura, Pesca y Desarrollo Rural. Memorias resumen de la Delegación Territorial en Almería. 2009 to 2018. Almería, Spain.

18. Nguyen, T.T.; Parat, M.O.; Shaw, P.N.; Hewavitharana, A.K.; Hodson, M.P. Traditional aboriginal preparation alters the chemical profile of carica papaya leaves and impacts on cytotoxicity towards human squamous cell carcinoma. PLoS ONE 2016, 11. [CrossRef]

19. Pandey, S.; Walpole, C.; Cabot, P.J.; Shaw, P.N.; Batra, J.; Hewavitharana, A.K. Selective anti-proliferative activities of Carica papaya leaf juice extracts against prostate cancer. Biomed. Pharmacother. 2017, 89, 515-523. [CrossRef]

20. Chan, Y.K.; Paull, R.E. Papaya Carica papaya L., Caricaceae. In The Encyclopedia of Fruits and Nuts; CAB International Publishing: Wallingford, UK, 2008; p. 954.

21. Food and Agriculture Organization of the United Nations (FAO) Roma Ital. Crop data. World Production of Papayas in Tons. 2019. Available online: http://www.fao.org/faostat/en/\#data/QC (accessed on 13 June 2019).

22. European Commission. Trade. Export Helpdesk. Estadísticas. 2019. Available online: https://rade.ec.europ a.eu/tradehelp/es/estadisticas (accessed on 10 July 2019). 
23. Pérez-Hernández, E. Ensayo de Variedades de Papaya 2013-2015. Available online: http://www.agrocabildo. org/publica/Publicaciones/subt_599_Var\%20papaya\%20web.pdf (accessed on 23 January 2019).

24. Camacho, F.F.; Fernández, R.E.J. El Cultivo de Sandía Apirena Injertada, Bajo Invernadero, en el Litoral Mediterráneo Español. Available online: https://www.publicacionescajamar.es/pdf/series-tematicas/agricul tura/el-cultivo-de-sandia-apirena-injertada.pdf (accessed on 3 April 2019).

25. Semillas del Caribe. Technical Data Sheet of the Papaya Seed Intenzza. Available online: https://www.semill asdelcaribe.com.mx/wp-content/uploads/2015/10/FichaTecnicaIntenzza.pdf (accessed on 11 Jul 2019).

26. Santamaría, B.F.; Sauri, D.E.; Espadas, G.F.; Díaz, P.R.; Larqué, S.A.; Santamaría, J.M. Postharvest ripening and maturity indices for maradol papaya. Interciencia 2009, 34, 583-588.

27. Garcia, D.J.; Lovett, B.M.; You, F. Considering agricultural wastes and ecosystem services in Food-Energy-Water-Waste Nexus system design. J. Clean Pro. 2019, 228, 941-955. [CrossRef]

28. Colla, G.; Cardarelli, M.; Bonini, P.; Rouphael, Y. Foliar Applications of Protein Hydrolysate, Plant and Seaweed Extracts Increase Yield but Differentially Modulate Fruit Quality of Greenhouse Tomato. HortScience 2017, 52, 1214-1220. [CrossRef]

29. Testa, R.; Di Trapani, A.M.; Sgroi, F.; Tudisca, S. Economic analysis of process innovations in the management of olive farms. Am. J. Appl. Sci. 2014, 11, 1486-1491. [CrossRef]

30. Toresano Sánchez, F.A.; Camacho Ferre, F. Valoración de las diferentes labores culturales en los cultivos de tomate, pimiento, calabacín, pepino, sandía, melón, judía y berenjena; Agrupación Española de Entidades Aseguradoras de los Seguros Agrarios Combinados (Agroseguros); University of Almería: Almería, Spain, 2012.

31. Guzmán Díaz, G.A. Guía para el cultivo de la papaya (Carica papaya L). Available online: http://www.mag. go.cr/bibliotecavirtual/F01-0658papaya.pdf (accessed on 21 January 2019).

32. Jiménez Díaz, J.A. Manual práctico para el c ultivo de la p apaya Hawaiana. Earth Editorial. Available online: http://usi.earth.ac.cr/glas/sp/90022688.pdf (accessed on 21 January 2019).

33. Escamilla, G.J.L.; Saucedo, V.C.; Martínez, D.M.T.; Martínez, G.Á.; Sánchez, G.P.; Soto, H.R.M. Fertilización orgánica, mineral y foliar sobre el desarrollo y la producción de papaya cv. Maradol Organic, Mineral and foliar fertilization on development and production of papaya cv. Maradol. Terra Latinoamericana 2003, 21, 157-166.

34. Singh, D.K.; Ghosh, S.K.; Paul, P.K.; Suresh, C.P. Effect of Different Micronutrients on Growth, Yield and Quality of Papaya (Carica papaya L.) cv. Ranchi. Acta Hortic. 2010, 851, 351-356. [CrossRef]

35. Jeyakumar, P.; Amutha, R.; Balamohan, T.N.; Auxcilia, J.; Nalina, L. Fertigation Improves Fruit Yield and Quality of Papaya. Acta Hortic. 2010, 851, 369-376. [CrossRef]

36. Bhalerao, P.P.; Patel, B.N. Effect of foliar application of Ca, Zn, Fe and B on growth, yield and quality of papaya (Carica papaya) cv. Taiwan Red Lady. Indian J. Hortic. 2015, 72, 325-328. [CrossRef]

37. Migliaccio, K.W.; Schaffer, B.; Crane, J.H.; Davies, F.S. Plant response to evapotranspiration and soil water sensor irrigation scheduling methods for papaya production in south Florida. Agric. Water Manag. 2010, 97, 1452-1460. [CrossRef]

38. Food and Agriculture Organization of the United Nations (FAO). CODEX Alimentarius. International Food Standards. 2011. Available online: http://www.fao.org/fao-who-codexalimentarius/sh-proxy/es/?lnk=1\&url =https $\% 253 \mathrm{~A} \% 252 \mathrm{~F} \% 252 \mathrm{Fw}$ orkspace.fao.org $\% 252$ Fsites $\% 252$ Fcodex $\% 252 \mathrm{FStandards} \% 252 \mathrm{FCODEX} \% 2 \mathrm{BS}$ TAN\%2B183-1993\%252FCXS_183s.pdf (accessed on 1 August 2019).

39. Santamaría, F.; Mirafuentes, F.; Zavala, M.J.; Vázquez, E. Fruit quality of red papaya genotypes cultivated in yucatan, Mexico. Costa. Rica. 2015, 39, 161-167.

40. Consejería de Agricultura Ganadería Pesca y Desarrollo Sostenible. Memoria Resumen. Anuario de estadísticas agrarias y pesqueras de Andalucía. 2018. Available online: https:/www.juntadeandalucia.es/organismos/agricul turaganaderiapescaydesarrollosostenible/consejeria/sobre-consejeria/estadisticas/paginas/agrarias-anuario.ht $\mathrm{ml}$ (accessed on 10 July 2019).

41. Soler, M.; Delgado, M.; Reigaza, A. Estrategias de la horticultura familiar almeriense ante la crisis de rentabilidad. Available online: https://idus.us.es/xmlui/handle/11441/65754 (accessed on 30 July 2019).

42. Aldrich, R.A.; Bartok, J.J.W. Greenhouse Engineering. Available online: https://trove.nla.gov.au/work/198251 54 ?q\&versionId=23319706 (accessed on 12 July 2019).

43. Nelson, P.V. Greenhouse Operation and Management; Pearson Education: London, UK, 2013; p. 616.

44. Calatrava, J.; Villa, J.P. Inputs intensity, costs variation and economics results in protected horticulture: The case of tomato greenhouses in the Almerian coastline, Spain. Acta Hortic. 2012, 927, 847-853. [CrossRef] 
45. Garrido, G.M.P.; López, P.R.; Lorbach, K.M.; Polonio, B.D.; Manrique, G.T.; Simón, J.V. Caracterización de los Invernaderos de Andalucía. Available online: https://www.google.com/url?sa=t\&rct=j\&q=\&esrc=s\&source $=$ web\&cd=1\&cad=rja\&uact=8\&ved=2ahUKEwiUsOT5rrDjAhVwD2MBHb_zBdIQFjAAegQIARAC\&url =https $\% 3 \mathrm{~A} \% 2 \mathrm{~F} \% 2 \mathrm{Fwww}$.juntadeandalucia.es $\% 2$ Fagriculturaypesca $\% 2$ Fobservatorio $\% 2$ Fservlet $\% 2$ FFron tController\%3Fec\%3Ddefault\%26action\%3DDownloadS\%26table\%3D11031\%26element\%3D1586184\%26 field\%3DDOCUMENTO\&usg=AOvVaw1iPD5ZrOEeBd_OtLDz45UZ (accessed on 12 July 2019).

46. Torres, J.; Valera, D.L.; Belmonte, L.J.; Herrero-Sánchez, C. Economic and social sustainability through organic agriculture: Study of the restructuring of the citrus sector in the "Bajo Andarax" District (Spain). Sustainability 2016, 8, 918. [CrossRef]

(C) 2019 by the authors. Licensee MDPI, Basel, Switzerland. This article is an open access article distributed under the terms and conditions of the Creative Commons Attribution (CC BY) license (http://creativecommons.org/licenses/by/4.0/). 